УДК 159.9.072.422

DOI https://doi.org/10.32838/2709-3093/2021.1/02

\title{
Васюк К.M.
}

Донецький національний університет імені Василя Стуса

\section{ПСИХОЛІНГВІСТИЧНІ ОСОБЛИВОСТІ ЗУМИСНИХ НЕПРАВДИВИХ ВИСЛОВЛЮВАНЬ}

У статті представлений аналіз основних психолінгвістичних технік детекиії брехні $i$ порівняльний аналіз їх ефективності. На основі аналізу наявних досліджень із иього питання було виділено кілька ключових ознак у мовленні, які можуть бути використані як можливі показники діагностики зумисного обману. Для перевірки ефективності иих ознак у детекиї обману був проведений лабораторний експеримент з використанням техніки спостереження, метою якого було доведення гіпотези, що психолінгвістичні засоби є ефективними у виявленні зумисного обману.

Використано 22 діагностичних показники, які порівнювалися у правдивих $і$ брехливих висловлюваннях за частотою появи. Основним методом дослідження було спостереження. Перевірка гіпотези здійснювалося шияхом порівняння визначених діагностичних показників у одних і тих же досліджуваних у ситуачї продукування правдивих $і$ зумисне неправдивих висловлювань. У результаті було встановлено, щз кілька ознак мають достовірні відмінності у частоті появи в зумисних неправдивих повідомленнях порівняно із правдивими.

У неправдивих повідомленнях особливо значущим є зменшення кількості деталей, збільшення частоти вживання безособових конструкиій, контекстуальних вставок, опису дій інших, порушення логічної структури повідомлення і корегування слів. Також спостерігалося збільшення тривалості і кількості пауз, надмірних узагальнень у висловлюваннях, зменшення кількості деталей.

3 метою встановлення можливих зв'язків між частотою появи виділених ознак окремо у правдивих і неправдивих повідомленнях був здійснений кореляційний аналіз. У результаті вдалося встановити, щьо брехливі і правдиві повідомлення в одних і тих же досліджуваних мають різні співвідношення виділених діагностичних ознак, які значимо корелюють між собою. Таким чином, нам вдалося визначити два типи осіб, які мають відмінності у способах формування зумисного неправдивого висловлювання, зокрема, стратегії його побудови і емоиіï, які супроводжують промову.

Встановлено, що різні психолінгвістичні ознаки зумисного неправдивого повідомлення зумовлені відмінностями в емочійних станах особистості під час продукування зумисного неправдивого висловлювання. Перший тип має високий рівень страху перед розкриттям обману. Це зумовлює збільшення пауз, мовних помилок, обмовок, порушення логічної структури тексту. Другий тип переживає задоволення від процесу обману, що супроводжується зростанням кількості цитувань, деталізаиії і вставних конструкцій.

Ключові слова: детекція, дискурс, логічна структура, обман, психолінгвістичні ознаки.

Постановка проблеми. Комунікація завжди $\epsilon$ основою взаємодії, що супроводжує будь-яку діяльність людини. Для досягнення своїх цілей у процесі спілкування комунікатори інколи вдаються до не зовсім етичних способів і маніпуляцій, приховування або навіть викривлення інформації. Тому у психології міжособистісних відносин існує досить значний інтерес до теми детекції обману.

Обман не завжди трактується однозначно, тому виникає необхідність виділити його види. Так, В.В. Знаков виділяє кілька видів обману [2, с. 32]. Зокрема, ми можемо виділити:
- ненавмисний обман, коли суб' єкт сам не знає правильної інформації, а тому вважає, що говорить правду;

- зумисний обман, коли суб'єкт спеціально викривлює інформацію $з$ певною метою. Це може виявлятися у двох формах: приховування інформації і власне іiі викривлення.

Зумисний обман не завжди вважається суто негативним явищем. Бувають ситуації, коли він рятує, зберігає стосунки або покращує самопочуття (у випадку з компліментами), але все ж у більшості випадків його вплив - негативний, він $\epsilon$ засобом маніпуляції оточуючими. Поширення 
брехні в сучасному світі вражає, навіть попри збільшення арсеналу засобів іiі детекції. Так, дослідниця Б. де Пауло довела, що в середньому добропорядна людина говорить неправду зумисне тричі на день. Щоб не стати жертвами такої маніпуляції, бажано володіти ефективними засобами ії розпізнання [7, с. 12].

Аналіз останніх досліджень і публікацій. Останнім часом особливої популярності набули два способи виявлення брехні: поліграфологічний, який грунтується на фіксації фізіологічних реакцій на питання й аналізі їх відмінностей у разі неправдивої відповіді; візуальна діагностика, що аналізує невербальні реакції людини в процесі спілкування. До них відноситься й аналіз рухів, міміки, мікровиразів обличчя, рухів очей. Ці засоби розроблялися як у вітчизняній (В.В. Знаков, Н.В. Романова, Є. Спіріца), так і у зарубіжній психології (А. Врій, Т. Левін, А. Піз, П. Екман, О. Фрай). Однак невербальні засоби не вичерпують усього розмаїття ознак, за якими можна ефективніше здійснювати детекцію обману, тому одночасно почали розроблятися психолінгвістичні засоби детекції, які іноді називають неінструментальними.

Одним із найперших цю проблему проаналізував у своїх працях засновник вітчизняної психолінгвістики О.О. Леонтьєв. Він не лише розробляв методологічні основи психолінгвістики, але й окреслив основні напрями її прикладного застосування: дитяча психолінгвістика, патопсихолінгвістика (витоки зі школи О.Р. Лурія), застосування аналізу тексту у кримінальному процесі (Н. Лущихіна, Т. Рябова) [4, с. 11]. Нині ці засоби не надто популярні через низьку представленість практичних їх аспектів у доступних широкому читачу публікаціях [7, с. 44].

Детекція обману - надзвичайно складний процес із великим відсотком індивідуальної варіативності показників, який потребує системного підходу. Тобто у практиці детекції потрібно аналізувати відразу велику кількість параметрів і лише потім робити висновок про ступінь правдивості висловлювання. Також необхідно враховувати, що емоційний супровідбрехні буваєрізним-відстраху розкриття до радості від вдалого маніпулювання.

Розрізняються також мотиви і форми подачі брехні. Наприклад, П. Екман виділяє такі види:

1. Приховування - індивід не повідомляє частину інформації, хоча про інші факти говорить правду.

2. Напівправда - один із найскладніших для детекції видів обману і в той же час найпоширеніший у спілкуванні, коли неправдива інформа- ція подається разом із правдивою. Ці компоненти важко відокремити. Крім того, ознаки брехні виявляються не так явно.

3. Омана (незумисна брехня), коли повідомляється інформація, яка не відповідає дійсності, але індивід не знає про це і щиро вірить, що інформація правдива. У цьому випадку виявити обман за допомогою відомих засобів детекції не можливо.

4. Зумисна брехня, коли індивід зумисне використовує обман у досить великому повідомленні. Цей вид обману є найбільш простим у детекції як інструментальними, так і неінструментальними засобами. Логічно припустити, що усі ці види мають різні ознаки, тому універсального правила детекції не існує. Складність цієї проблеми зумовлює необхідність створення окремої науки, яка б займалася питаннями детекції різних форм обману. Так, А.В. Ленець пропонує iї назву - ментіологія [2, с. 37].

Думку про можливість діагностики мовленнєвого вираження обману як взаємозв'язку форми і змісту дискурсу висловлював ще Д. Белінджер. Нині, як зазначає I. Морозова, у психолінгвістиці існує два основні напрями дослідження обману:

1. Аналіз мовних об'єктів, які виражають семантику повідомлення (Н. Арутюнова, I. Морозова).

2. Вивчення прагматичних характеристик неправдивих висловлювань (Дж. Остін, Т. Ніколаєва, С. Плотнікова, В. Маховський) [5, с. 10].

У дослідженні Л. Єрмакової та С. Лозової акцент робиться на порушенні логічної будови повідомлення. Вони вважають, що, говорячи брехню, індивід допускає більше мовленнєвих помилок і повторів, а також збільшується тривалість пауз [1, с. 111]. До того ж відбувається зменшення кількості структурних одиниць дискурсу (у цьому випадку як одиниці тексту аналізувалися склади). Щоб контролювати повідомлення, індивід намагається говорити коротшими фразами i взагалі продукувати менше тексту.

Із цим згодний і О. Соловей, який також виділяє як надійні засоби детекції збільшення кількості і тривалості пауз, нерелевантні повтори, заповнення пауз у тексті вигуками та повторами, вживання більшої кількості стереотипних слів і кліше. Також збільшується частота незавершених висловлювань, неологізмів і мовних помилок. Якщо дивитися на рушійні чинники цих ознак, то усі вони мають єдину причину - дисбаланс емоційного стану доповідача [4, с. 99]. Сучасні дослідження низки вчених (А. Врій, Т. Левін, С. МакКорнак) демонструють перспективність розробки 
психолінгвістичних засобів детекції, до того ж цей діагностичний пласт ще не досить розроблений.

Постановка завдання. Метою дослідження було визначити психолінгвістичні ознаки брехні та здійснити експериментальну перевірку їх ефективності з перспективою розробки в подальшому дієвих засобів детекції.

Об'сктом дослідження виступили лінгвістичні та екстралінгвістичні характеристики усного повідомлення. Предметом - лінгвістичні та екстралінгвістичні характеристики правдивих і зумисно неправдивих повідомлень.

Гіпотеза дослідження полягала у тому, що в зумисно неправдивих повідомленнях порівняно із правдивими спостерігаються якісні та кількісні зміни лінгвістичних та екстралінгвістичних параметрів мовлення. Також ми припустили, що ці параметри складають певний профіль співвідношення частоти їх появи, за яким можна визначити міру правдивості висловлювання.

У результаті теоретичного аналізу праць низки дослідників (П. Екмана, А. Врія, Т. Левіна, О. Фрая) загалом було виділено 12 психолінгвістичних параметрів, які поєднані у такі тематичні групи:

1. Деталізація: відсутність потрібної кількості або надмірна кількість деталей, незвичайні подробиці, надмірне узагальнення.

2. Мовні помилки: обмовки, корекція слів у процесі вимови, повтори слів і перепитування, збільшення кількості вигуків.

3. Особливі мовні прийоми: збільшення кількості вигуків, контекстуальні вставки, безособові конструкції, опис дій іншого, а не своїх або цитування прямою мовою.

У результаті проведення експерименту не усі 3 цих показників виявилися суттєвими, а деякі взагалі не виокремилися під час проведення дослідження. Процедура експерименту полягала в комплексному аналізі виділених параметрів діагностики шляхом порівняння частоти їх вияву в одних і тих же досліджуваних у ситуації, коли вони говорили правду і коли зумисне говорили неправду. Загалом кожен досліджуваний робив по два неправдивих і два правдивих висловлювання як відповіді на відкриті питання дослідника, яких досліджувані заздалегідь не знали.

Загальний час кожного повідомлення складав від 50 до 70 сек. Контингент досліджуваних склали 50 досліджуваних віком від 18 до 27 років, із яких 11 осіб чоловічої статі і 39 - жіночої. Таким чином, ми здійснили 200 проб, із яких 100 містили цілком правдиву інформацію, решта - повністю неправдиву, викривлену зумисно.
Для контролю за фактом обману досліджуваним пропонувалися готові тексти, які вони мали запам'ятатиі відтворити векспериментальній ситуації. Знання тексту перевірялося попереднім опитуванням. Обсяг текстів був приблизно однаковий i був розрахований на 1,5-2 хвилини промови. Час міг дещо коливатися залежно від темпу мовлення конкретного індивіда. Також враховувався той факт, що текст міг скорочуватися досліджуваними під час переказу, тому його первинний обсяг був більшим за реально відтворений досліджуваними.

Виклад основного матеріалу дослідження. На першому етапі дослідження ми здійснили порівняльний аналіз виділених вище ознак, їх динаміку в частоті вияву у правдивих і брехливих висловлюваннях одних і тих же досліджуваних. Зазначимо, що ми свідомо обрали стратегію порівняння вказаних діагностичних параметрів в одних досліджуваних у різних ситуаціях, тому що визначити діагностичну цінність ознаки можна, лише порівнявши частоту їх появи у правдивих і зумисне неправдивих висловлюваннях. Оскільки вибірки були зв'язаними, то для статистичної обробки використовувався G-критерій знаків.

Аналіз проводився за сумарними показниками двох проб кожного досліджуваного (двох правдивих і двох неправдивих). У результаті були виявлені статистично достовірні відмінності у виявах ознак, представлених в табл. 1. Емпіричним показником у цьому критерії вказується нетиповий зсув (тобто тенденція в бік збільшення чи зменшення частоти ознаки, яка зустрічається рідше). При цьому не враховувалися нульові показники, тобто випадки, коли зміни в частоті ознаки не спостерігалося. Як ми вже зазначали, всі ці параметри дуже індивідуальні, тому їх можна порівнювати лише у зв'язаних вибірках.

У цьому статистичному критерії збільшення рівня статистичної значущості відбувається при зменшенні емпіричного показника. Також важливо, що досягнення певного рівня статистичної значущості ще не свідчить про реальну відмінність, оскільки він не враховує нульовий показник, коли зміни в частоті появи ознаки не відбувалось.

Один із основних показників, який ми аналізували, - надмірна деталізація. Вона виражається у згадуванні неважливих, непотрібних фактів і описів, які не несуть важливої для сюжету розповіді інформації. За цим показником досліджувані розподіляються на два типи: ті, які намагаються уникати зайвих деталей, говорити «взагалі»; і ті, хто надмірно деталізує, щоб повідомлення виглядало достовірнішим. На користь цього свідчить той 
Таблиця 1

Статичні показники G-критерію знаків у показниках частоти психолінгвістичних ознак у правдивих і зумисне неправдивих повідомленнях

\begin{tabular}{|c|c|c|}
\hline Діагностичний показник & Емпіричне значення G-критерію & Критичне значення G-критерію \\
\hline Надмірна деталізація & 12 & $\begin{array}{l}\mathrm{P} 0,05=13 \\
\mathrm{P} 0,01=11\end{array}$ \\
\hline Незвичайні подробиці & 4 & $\begin{array}{l}\mathrm{P} 0,05=4 \\
\mathrm{P} 0,01=2\end{array}$ \\
\hline Обмовки & 2 & $\begin{array}{l}\mathrm{P} 0,05=4 \\
\mathrm{P} 0,01=2\end{array}$ \\
\hline Корекція слів & 9 & $\begin{array}{c}\mathrm{P} 0,05=10 \\
\mathrm{P} 0,01=8\end{array}$ \\
\hline Повтори слів & 18 & $\begin{array}{c}\mathrm{P} 0,05=11 \\
\mathrm{P} 0,01=9\end{array}$ \\
\hline Вигуки & 14 & $\begin{array}{l}\mathrm{P} 0,05=16 \\
\mathrm{P} 0,01=13\end{array}$ \\
\hline Вставні конструкції & 13 & $\begin{array}{l}\mathrm{P} 0,05=16 \\
\mathrm{P} 0,01=14\end{array}$ \\
\hline Опис дій іншого & 12 & $\begin{array}{c}\mathrm{P} 0,05=10 \\
\mathrm{P} 0,01=8\end{array}$ \\
\hline Безособові конструкції & 12 & $\begin{array}{c}\mathrm{P} 0,05=11 \\
\mathrm{P} 0,01=9\end{array}$ \\
\hline Пряма мова & 11 & $\begin{array}{c}\mathrm{P} 0,05=10 \\
\mathrm{P} 0,01=8\end{array}$ \\
\hline
\end{tabular}

факт, що у повідомленні одного автора є чітка тенденція до того чи іншого способу деталізації. Якщо говорити об'єктивно, то ці показники залежать від суб' єктивної думки дослідника, але ми намагалися фіксувати лише факт появи таких деталізацій.

Статистичний аналіз за G-критерієм знаків показав високий рівень статистичної значущості відмінностей на рівні $\mathrm{p} \leq 0,01$. Порівняно із правдивими висловлюваннями у людей, які зумисне говорять неправду, спостерігається зростання деталізації (52\%), у 24\% фіксувалося зменшення кількості деталей, інші особи не змінювали цього показника.

Деталізація виявлялася у формі уточнень, шляхом збільшення кількості епітетів, згадувань власних назв, описів прогнозів на майбутнє. Загальною рисою таких деталізацій є відсутність змістовності, значення для розуміння основного сюжету повідомлення. Складається враження, що індивід використовує їх для заповнення паузи, яка потрібна йому для побудови сюжетної лінії повідомлення, яку він не встиг до кінця сформулювати.

Якщо судити про загальний обсяг тексту, який вимірювався кількістю семантичних одиниць, то цей показник теж варіює. Логічно було б припустити, що людина, говорячи правду, намагатиметься швидше завершити діалог. Ця ознака неоднозначно представлена у досліджуваних і не $\epsilon$ надійним показником. Можливе пояснення цьому можна знайти у працях О. Фрая, який описував різні супутні емоції при брехні [Фрай, 2007].
Особи чітко поділяються на тих, які переживають страх викриття під час брехні, й тих, які не відчувають особливих емоцій, тих, хто відчуває захоплення від вдалого обману. Отже, якщо емоції різні, то лінгвістичні засоби їх вираження теж будуть різними. Хоча логічно, що при переживанні страху людина уникатиме розгорнутих повідомлень, а при переживанні захоплення намагатиметься пролонгувати задоволення, продукуючи розгорнуті повідомлення. Але це припущення потребує додаткового підтвердження, тому що в цьому дослідженні ми не використовували методик виявлення супутніх емоційних станів.

Також деталізація виявляється у формі незвичайних подробиць. У роботах О. Фрая були припущення, що у правдивих висловлюваннях ця ознака зустрічається частіше [8, с. 246]. Людина, яка бреше, не має часу вигадувати щось неординарне. Вона радше піде по стандартному шляху, щоб зменшити ризик заплутатися у власній брехні. Наше дослідження підтвердило цей факт, тому що рівень статистичної значущості відмінностей склав $\mathrm{p} \leq 0,05$, але такий достовірний результат не можна вважати досить надійною підставою, оскільки недоліком цього статистичного критерію $€$ неврахування нульових показників (тобто випадків, де не було зміни показника ні в бік збільшення, ні в бік зменшення) і таких показників у цій шкалі було $28 \%$. Це досить значний показник, щоб вважати його надійним детекції 
обману, оскільки кількість випадків, коли використовуються незвичайні подробиці, незначна (в середньому не більше 2-х) у тих, хто використовував цей психолінгвістичний засіб.

Наступним параметром діагностики були вставні мовні конструкції. Це словосполучення, які не несуть змістовної інформації, а просто вставляються як додаткові речення. Наприклад, «чесно кажучи», «як я думаю», «я точно не знаю». У брехливих повідомленнях збільшується кількість вставних конструкцій (у середньому 2,56 для брехливих повідомлень і 0,5 для правдивих) і контекстуальних вставок (у середньому 1,47 для брехливих повідомлень і 0,13 для правдивих). При цьому в обох випадках рівень статичної достовірності відмінностей перевищує $\mathrm{p} \leq 0,01$.

Безособові конструкції виражають дистанціювання доповідача від змісту неправдивого повідомлення, тому що воно не має для нього особистісного значення. Це вирази на кшталт «усім це відомо» замість «я це знав», «захід сонця був красивим» замість «я бачив красивий захід сонця». Вставні конструкції, вірогідно, виконують таку ж функцію. Найпоширенішими є такі: «чесно кажучи», «абсолютно ні», «можливо», «якщо можна так висловитись». Ці мовні засоби призначені не лише для виграшу певного часу на продумування стратегії брехливого повідомлення, але й підкреслюють «щирість» доповідача. Наприклад, ми часто бачимо у брехливих повідомленнях парадоксальну для нього вставну конструкцію «чесно кажучи». $\mathrm{C}$ теоретичні твердження щодо того, що під час зумисних неправдивих повідомлень людина частіше описує дії інших, а не власні, тобто дистанціюється від предмету опису, але в нашому дослідженні це припущення підтвердження не знайшло. Ця стратегія частіше застосовується у такому типі брехні, як приховування. Але додаткову емпіричну перевірку цієї гіпотези ми не проводили.

Найбільш суттєвою у детекції брехні, на нашу думку, є такі ознаки, як граматична структурованість і логічність тексту. Оскільки брехня $€$ вигадкою, часто імпровізованою, то на її формулювання потрібен не лише певний час (що виражається у збільшенні пауз). Часто, починаючи говорити, індивід не формує усе повідомлення загалом. Фабула повідомлення складається не відразу, а формується під час мовлення, що може провокувати певні невідповідності між частинами повідомлення, логічні помилки, важкість у підборі потрібних слів, порушення хронології подій, плутанину у деталях, тому що в цей момент доповідач зайнятий формуванням стратегії тексту. Звичайно, що всі ці ознаки не будуть дієвими у підготовленій брехні. Але в нашому експерименті досліджувані продукували якраз брехню-імпровізацію, не маючи змоги підготувати ії заздалегідь.

Також до цього класу ознак можна віднести мовні помилки та корегування слів. Ми припустили, що вимушене формування висловлювання на ходу, без попереднього задуму буде провокувати збільшення мовних помилок, коли людина починає говорити одне слово, а потім виправляється і говорить інше, тобто корегує його. Але в нашому експерименті частота появи такої ознаки була невеликою, тому статистична достовірність відмінностей між вибірками встановлена на рівні $\mathrm{p} \leq 0,05$. Можливо, подібна ознака пов'язана не лише 3 тим, чи бреше людина, а й із загальними комунікативними вміннями, здатністю швидко формулювати усне повідомлення.

До мовних помилок можна віднести обмовки, але статистична достовірність цього показника ще не свідчить про його надійність у питанні детекції зумисного обману. Припускаємо, що він є специфічним для певної категорії осіб, вірогідно, більш тривожних. Частка таких осіб у вибірці складає лише $28 \%$ від загальної кількості досліджуваних.

Нечасто зустрічається і показник «Використання прямої мови». Він не тільки не досяг рівня статистичної значущості, але і взагалі зустрічався лише у $24 \%$ досліджуваних. Щодо зменшення чи збільшення такого показника у ситуаціях правдивих та зумисне неправдивих висловлювань у дослідженнях О.О. Леонтьєва (4) було висунуте припущення, що під час формулювання неправдивого повідомлення індивід використовує дещо інші мовні прийоми, ніж для формулювання правдивого. Цитування інших може використовуватися доповідачем для підвищення правдоподібності повідомлення в ситуаціях зумисного обману. Така тенденція спостерігалася у 14\% досліджуваних, у яких кількість цитувань різко зростала в ситуації зумисного обману. Також значна частина досліджуваних взагалі не використовувала цей лінгвістичний прийом у своєму мовленні під час проведення дослідження (частка таких досліджуваних склала 76\%). 3 огляду на це вважати такий показник корисним у детекції обману немає підстав.

Останнім показником, який ми діагностували у мовленні, були вигуки. До вигуків відносилися додаткові фонеми у мовленні, які не несуть смислового навантаження. Здебільшого їх набір був незначним. Зокрема, найчастіше спостерігалися вигуки для заповнення пауз по типу звуку «е-е-е», 
«ну», «ось», «а-а-а», «ой». Загалом цей показник виявився найбільш численним. Жоден респондент не зміг уникнути вживання їх у мовленні. Звичайно, були випадки їх відсутності в якійсь із проб, але, враховуючи те, що кожен досліджуваний формулював чотири доповіді, абсолютно уникнути їх використання нікому не вдалося. Здебільшого превалювала тенденція до збільшення кількості вигуків у зумисне неправдивих повідомленнях. Вона спостерігалася у $60 \%$ досліджуваних, ще у $28 \%$ мала місце тенденція до зниження кількості вигуків, лише у $12 \%$ цей показник залишився незмінним.

Статистична достовірність зміни частоти появи ознаки у зумисне неправдивих висловлюваннях порівняно з правдивими виявилася на рівні $\mathrm{p} \leq 0,05$. Частота збільшення появи цієї ознаки робить ії досить важливою у детекції зумисного обману. Як відомо, кількість вигуків збільшується у випадках хвилювання досліджуваних, а також за умови його відсутності.

Отже, на основі статистичного аналізу складається перелік ознак брехливого повідомлення, що включає такі з них: збільшення кількості пауз і їхньої тривалості, частоти вживання безособових і вставних мовних конструкцій, порушення деталізації як у бік збільшення, так і в бік зменшення, неструктурованість тексту і порушення логічних зв'язків між його частинами, опис дій іншого, а не своїх, збільшення кількості незвичайних подробиць.

Зазначимо дві суттєві для діагностики деталі: через те, що поняття «збільшення кількості деталей» $\epsilon$ відносним, потрібно обов'язково здійснювати порівняння їх частоти в різних висловлюваннях одної і тісї ж людини. Для детекції брехні під час першого спілкування вони не будуть надійними. Хоча це можна сказати і про всі інші засоби. Детекція брехні тим і складна, що потребує первинної специфікації поведінкових лінгвістичних ознак, характерних саме для цієї особи.

Також ми вважаємо, що жодна із перерахованих ознак не може бути надійною і використовуватися сама по собі, а завжди застосовується комплексно 3 іншими ознаками. Для прийняття рішення про правдивість повідомлення потрібно зафіксувати якусь критичну кількість цих параметрів. Точна кількість необхідних параметрів нині не представлена в наукових дослідженнях і потребує додаткової перевірки. Як свідчать дані нашого експерименту, у зумисне неправдивих повідомленнях одночасно зустрічаються 3 і більше такі ознаки. Вони складають певний поведінковий «портрет» людини, яка зумисне говорить неправду залежно від мотивів і супутніх емоцій.

Висновки. Таким чином, при аналізі відмінностей між брехливими і правдивими повідомленнями статистично підтвердилися деякі з виділених ознак, зокрема, збільшення деталізації, кількості вигуків, корегування слів, обмовки, використання вставних слів і безособових конструкцій.

Ми не будемо стверджувати, що інші ознаки, виділені дослідниками в різних джерелах, не $є$ надійними, але вони можуть бути специфічними для певних соціальних груп. Оскільки в нашому дослідженні брали участь студенти, які здебільшого мають лінгвістичні здібності, вищі за середньостатичного громадянина, то деякі з цілком вірогідних ознак у них були не представлені, зокрема, корегування слів, вживання вигуків i мала кількість синонімів. Але і статистично підтверджені ознаки $є$ в достатній кількості для того, щоб мати змогу надійно оцінити повідомлення на предмет достовірності.

Кореляційний аналіз показав, що існують чіткі кластери ознак брехні, попри відсутність повного циклу зв'язків між ознаками, але вони пов'язані між собою через опосередковуючі ланки. Ми виділили чотири класи ключових ознак, які потрібно розглядати у сукупності по принципу збільшення надійності зі збільшенням кількості наявних ознак. Перспективним у цьому напрямі був би аналіз психолінгвістичних характеристик інших видів брехні, зокрема, приховування або напівправди.

Головними стратегічними напрямами подальшого дослідження вважаємо необхідність встановлення кореляційних зв'язків між виділеними ознаками, які дозволять окреслити можливі типи осіб, які використовують зумисний обман, виділити своєрідні «стилі обману», а також встановити їх зв'язки із певними особистісними рисами. Це дало б змогу детальніше розібратися 3 мотивами використання зумисного обману в безпосередньому спілкуванні. Також важливим $є$ врахування змісту брехливого повідомлення, оскільки це дослідження проводилося в умовах, коли брехливе повідомлення практично не включає правдивого контенту, у той час як в реальних умовах індивіди використовують змішані форми повідомлень, тобто частково неправдиві. 


\section{Список літератури:}

1. Белянин В.П. Психолингвистика : учебник. Москва : Московский психолого-социальный институт. 2004. $232 \mathrm{c}$.

2. Горелов И.Н. Невербальные компоненты коммуникации. Москва : Стереотип. 2014. 112 с.

3. Знаков В.В. Западные и русские традиции в понимании лжи. Размышления российского психолога над исследованиями Пола Экмана. Экман П. Психология лжи. Санкт-Петербург, 1999. С. 243-268.

4. Леонтьев А.А. Прикладная психолингвистика речевого общения и массовой коммуникации. Москва : Смысл. 2008. 272 с.

5. Майорчак Н.М. Психологічні аспекти категорії брехні у роботах українських і зарубіжних вчених. Науковий вісник Львівського державного університету внутрішніх справ. Серія: Психологічна, 2013. Вип. 1. С. 96-104.

6. Стернин И.А. Введение в речевое воздействие. Воронеж : АСТ. 2001. 173 с.

7. Фрай О. Детекция лжи и обмана. Санкт-Петербург : Питер. 2005. 358 с.

8. Экман П. Психология лжи. Санкт-Петербург : Питер. 1999. 272 с.

\section{Vasuk K.M. PARALINGUISTIC FEATURES OF DECEPTION MESSAGES}

The article is dedicated to the analysis of main psycholinguistic technologies detection of lie and comparative analysis of their efficiency. We have made a detailed analysis real investigation of this question. As result, we have selected few psycholinguistic signs of speech. We characterized them as the possible sign of a lie. As result, the laboratory experiment checked these statements and used an observation as a method. Psycholinguistic technologies are more reliable methods of a lie detection than others.

The analysis was carried out using comparing 22 psycholinguistic signs of speech in the same subjects in the true and false messages. The main method of investigation was the observation. The verification of the hypothesis was carried out by comparing the diagnostic indicators of some test subjects in the lie and true massages. As result, we found out that single features were very different in the frequency of truth and lie in the same subjects.

There were seven reliable features of lie detection, which have statistic verification of differences in the lie and true speeches. They are an increase and significant decrease number of details, increase of use of impersonal constructers, contextual inserts, description of another's actions, the logic structure of the text, reservations, word corrections. There is increasing in the number and duration of pauses in the speech, aspiration to generalize and to reduce the number of details in the lie massages.

We have made a correlation analysis to relate the interconnection between the frequency of appearance of the features. As a result, it was revealed that true and false massages have different profiles of features, with reliable correlation. Also, we have discovered two types of liars. They use different methods and strategies of a lie speech and have different emotions during communication.

The differences in psycholinguistic features of a lie are explained with different emotions in a lie process. The first type has a high level of fear of exposure. It has some features. They increase the number of pauses, mistakes, interjections, violations of logic in the text. The second type relives emotion "delight of deception", which facilitates increasing citation, detailing, using plug-in construction.

Key words: discourse, detection, logic structure, lie, psycholinguistic feature. 